\title{
Nadir bir disfaji nedeni: Özofageal Pemfigus Vulgaris
}

\section{A rare cause of dysphagia: Pemfigus Vulgaris}

Murat SARIKAYA ${ }^{1}$, Zeynal DOĞAN ${ }^{1}$, Bilal ERGÜL ${ }^{1}$, Levent FILIK ${ }^{1}$, Nesibe TAŞER ${ }^{2}$

Ankara Eğitim ve Araştırma Hastanesi ${ }^{1}$ Gastroenteroloji Kliniği, ${ }^{2} I_{c ̧}$ Hastalıklan Kliniği, Ankara

Pemfigus mukoz membranları ve cildi tutan önemli morbidite ve mortaliteye neden olabilen otoimmün bir hastalıktır. Pemfigus vulgaris daha çok oral mukozayı etkilese de özofagus tutulumu da gözlenebilmektedir. Burada disfaji ve odinofaji şikayetleriyle yapılan endoskopisinde yeni tanı konulan bir pemfigus vulgaris vakasinı sunuyoruz.

Anahtar kelimeler: Özofageal pemfigus vulgaris, disfaji, odinofaji

\section{GİRIŞ}

Pemfigus mukoz membranı ve cildi tutan, keratinosit hücre yüzeyine karşı yönlendirilmiş IgG antikorlarının yol açtığı akantoliz (keratinosit-keratinosit adezyon kaybi) sonucu intraepitelyal vezikül ve bül oluşumu ile karakterize otoimmun ve yaşamı tehdit eden bir hastalıktır (1). Pemfigusun başlıca alt grupları Pemfigus Vulgaris (PV), Pemfigus Foliaseus ve Paraneoplastik Pemfigusdur. Pemfigus'un en sik görülen alt tipi PV'dir (2). PV her iki cinste de eşit oranda görülmektedir. Coğrafik olarak farklı dağılım gösterse de insidansı yılda 100.000'de 0,1 ile 0,5 arasında değişmektedir (3)

Hastalı̆ı̆ı seyri sırasında hemen hemen bütün vakalarda çok katl yassı epitel mukozası özellikle de oral mukoza tutulur. Farengolarengeal, konjonktival, genital, anorektal mukoza daha az sıklıkla tutulur (4). Burada yaklaşık 3 aydır yutma güçlüğü ve göğsünde ağrı şikayetleri ile yeni tanı alan bir PV vakası sunacağız.

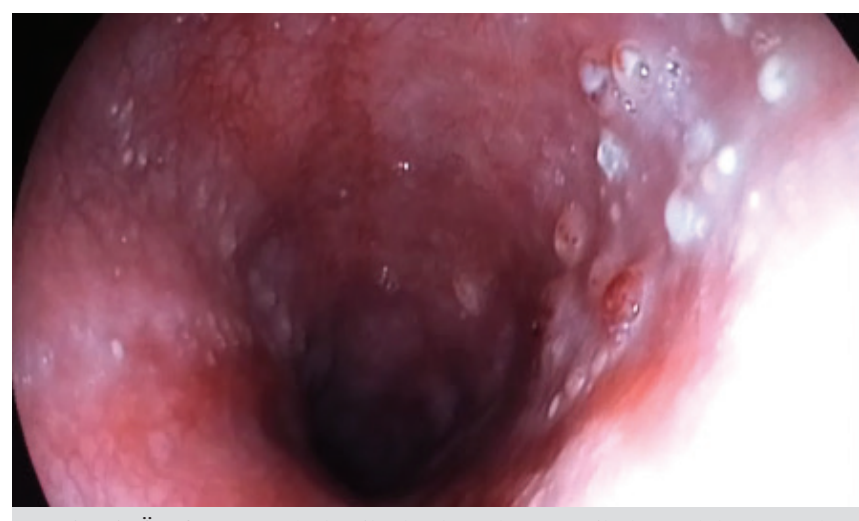

Resim 1. Özofagusta endoskopik olarak gözlenen veziküler-nodüler lezyonlar

Sarıaya M, Doğan Z, Ergül B, et al. A rare cause of dysphagia: Pemfigus Vulgaris. Endoscopy Gastrointestinal 2014; 22: 16-17.
Pemphigus is an autoimmune disease that causes significant morbidity and mortality by affecting the mucous membranes and skin. Pemphigus vulgaris affecting especially the oral mucosa can also be observed in the esophagus. Herein, we describe a patient with odynophagia and dysphagia who was diagnosed as pemphigus vulgaris.

Key words: Esophageal pemphigus vulgaris, dysphagia, odynophagia

\section{OLGU SUNUMU}

46 yaşında kadın hastanın yaklaşık 3 ay önce yutma güçlüğü ve göğsünde ağrı şikayetleri başlamış. Hastaya özofajit ön tanısıyla dış merkezde proton pompa inhibitörü tedavisi ve aljinik asit verilmiş. Şikayetlerinde düzelme olmayan hastanın son 1 aydırda şikayetleri artış göstermiş. Mevcut şikayetleriyle gastroenteroloji polikliniğimize başvuran hastaya üst gastrointestinal sistem endoskopisi yapıldı. Özofagus orta kesimde vezüküle-nodüler lezyonlar izlenerek biyopsi alındı (Resim 1). Biyopsi alınan bölgeden başlayarak özofagus lümenini çepeçevre saracak şekilde özofagus mukozasının alttaki dokudan ayrıldığı izlendi (Resim 2). Hastaya proton pompa inhibitörü ve sükralfat tedavisi başlandı. Hastada viral bir özofajit olabileciği düşünülerek viral markırları istendi ancak normal olarak saptandı. Diğer laboratuvar değerleri de normal olarak saptandi. Biyopsi sonucu Pemfigus ile uyumlu gelen hastaya dermatoloji kliniğinin önerisi ile steroid ve

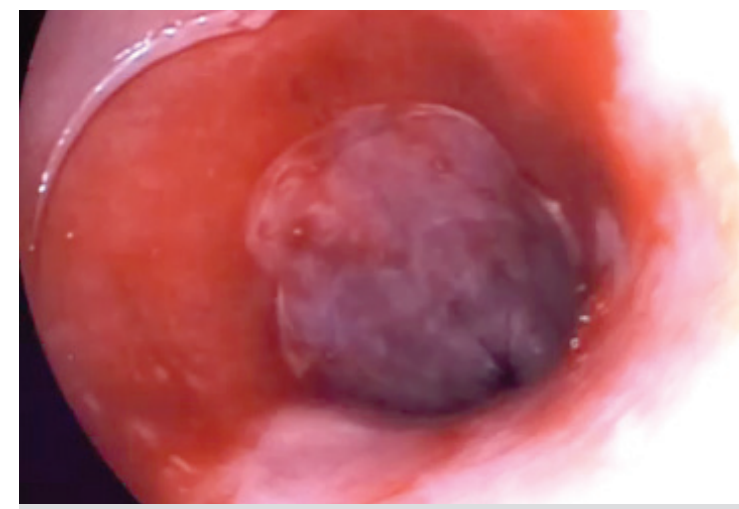

Resim 2. Özofageal mukozanın biyopsi alınmasıyla soyulması Gastroenteroloji Kliniği, Ulucanlar, Altındağ, Ankara E-posta: drmuratsarikaya@gmail.com Geliş Tarihi: 01.11.2013 Kabul Tarihi: 28.12.2013 
immünsupresif tedavi başlandı. Hasta takip altında olup tedavisi halen devam etmektedir.

\section{TARTIŞMA}

Asemptomatik özofagus tutulumu daha sık görülmesine rağmen odinofaji ve disfaji özofageal pemfigusun en sık görülen bulgularıdır. Özofageal mukozanın tamamının tutulumu ise çok nadirdir. Özofageal pemfigusda çoğunlukla kabarcıklar, erozyonlar ve eritem görülür. Tanıda kullanılan yöntemler; özofagoskopi ile birlikte sitoloji, biyopsi ve direk-indirek immünofloresan yöntemleridir (5).

PV'in tedavisinde sistemik kortikosteroidler oldukça etkili bir seçenektir. Oral mukoza ile sınırlı olan olgularda topikal kortikosteroidler kullanılabilir. Tedaviye intravenöz siklofosfamid, azatiyoprin, siklosporin, metotreksat gibi ilaçların eklenmesi kortikosteroid dozunda azalma sağlayabilir. Hastaların \%10 kadarı immünsupresif tedaviye rağmen, yara enfeksiyonu, elektrolit kaybı ve tedavi komplikasyonları gibi nedenlerden dolayı kaybedilmektedir (6).

PV mukozal tutulumun ön planda olduğu bir pemfigus tipidir. Daha çok oral tutulum olsa da asemptomatik özofagus tutulumu da sık görülmektedir. Özofageal pemfigus vakalarının az olmasının nedeni ise ilk muayenede özofagusa yeterince odaklanılmaması veya PV'in özofagus tutulumunun nadir olması nedeniyle olabilir. Bu sebeple özellikle de odinofaji ve disfaji gibi semptomları bulunan PV'li hastalarda rutin olarak özofagus da incelenmelidir. Ayrica sunulan vakada olduğu gibi daha önce tanı almamış bu tip semptomları bulunan hastalarda PV'in özofagus tutulumu da ayırıcı tanılar arasında düşünülmelidir.

\section{KAYNAKLAR}

1. Mihai S, Sitaru C. Immunopathology and molecular diagnosis of autoimmune bullous diseases. J Cell Mol Med 2007; 11:462-81.

2. Zeina B, Ali M, Mansoor S. Pemphigus vulgaris. eMedicine. Available at http://www.emedicine.com/derm/topic319.htm

3. Kneisel A, Hertl M. Autoimmune bullous skin diseases. Part 1: Clinical manifestations. J Dtsch Dermatol Ges 2011; 9:844-56.
4. Mignongna MD, Lo Muzio L, Galloro G, et al. Oral pemphigus: clinical significance of esophageal involvement: report of eight cases. Oral Surg Oral Med Oral Pathol Oral Radiol Endod 1997; 84:179-84.

5. Khamaysi I, Eliakim R. Esophageal Pemphigus Vulgaris: A rare manifestation revisited. Gastroenterol Hepatol 2008; 4:71-2.

6. Carson PJ, Hameed A, Ahmed AR. Influence of treatment of the clinical course of pemphigus vulgaris. J Am Acad Dermatol 1996; 34:645-52. 